The Comply-or-Explain Approach for Enforcing Governance Norms

Subrata Sarkar

Indira Gandhi Institute of Development Research, Mumbai

August 2015

http://www.igidr.ac.in/pdf/publication/WP-2015-022.pdf 


\title{
The Comply-or-Explain Approach for Enforcing Governance Norms
}

\author{
Subrata Sarkar \\ Indira Gandhi Institute of Development Research (IGIDR) \\ General Arun Kumar Vaidya Marg \\ Goregaon (E), Mumbai- 400065, INDIA \\ Email(corresponding author): ssarkar@igidr.ac.in
}

\begin{abstract}
In recent years the comply-or-explain approach for enforcing corporate governance norms has gained ground in regulatory parlance. The comply-or-explain approach has the advantage of tailoring governance norms to specific characteristics of individual companies which is believed to lead to more efficient corporate governance outcomes compared to the "one size fits all" approach that is often argued to be inherent in the comply-or-else approach. Yet, the effectiveness of the comply-or-explain approach presupposes the existence of many institutional conditions like ownership and control structure of companies, responsibility and transparency of their financial operations, efficiency of stock markets, and ability and incentives of shareholders to assess corporate behavior, all of which could take a long time to evolve and could be challenging especially for emerging economies. This article critically examines the relative advantages of the comply-or-explain approach vis-à-vis the more traditional comply-or-else approach and identifies the specific institutional conditions which are required for its success in achieving effective governance of companies.
\end{abstract}

Keywords: Corporate governance, strategic behavior, governance norms, enforcement, convergence

JEL Code: D22, D82, G34, G38

\footnotetext{
Acknowledgements:

Forthcoming in Corporate Governance in India: Challenge and Continuity, Indian Institute of Corporate Affairs, Oxford University Press, Publishers. I would like to thank Mrinmoyee Chaterjee for excellent research assistance in preparing this manuscript. The usual disclaimer applies.
} 


\title{
The Comply-or-Explain Approach for Enforcing Governance Norms
}

\author{
Subrata $\operatorname{Sarkar}^{1}$ (ssarkar@igidr.ac.in) \\ Indira Gandhi Institute of Development Research \\ A.K.Vaidya Marg, Mumbai 400 065, INDIA
}

July, 2015

\begin{abstract}
In recent years the comply-or-explain approach for enforcing corporate governance norms has gained ground in regulatory parlance. The comply-or-explain approach has the advantage of tailoring governance norms to specific characteristics of individual companies which is believed to lead to more efficient corporate governance outcomes compared to the "one size fits all" approach that is often argued to be inherent in the comply-or-else approach. Yet, the effectiveness of the comply-or-explain approach presupposes the existence of many institutional conditions like ownership and control structure of companies, responsibility and transparency of their financial operations, efficiency of stock markets, and ability and incentives of shareholders to assess corporate behaviour, all of which could take a long time to evolve and could be challenging especially for emerging economies. This article critically examines the relative advantages of the comply-or-explain approach vis-à-vis the more traditional comply-or-else approach and identifies the specific institutional conditions which are required for its success in achieving effective governance of companies.
\end{abstract}

JEL Classification Codes: D22, D82, G34, G38

\footnotetext{
${ }^{1}$ Forthcoming in Corporate Governance in India: Challenge and Continuity, Indian Institute of Corporate Affairs, Oxford University Press, Publishers. I would like to thank Mrinmoyee Chaterjee for excellent research assistance in preparing this manuscript. The usual disclaimer applies.
} 


\subsection{Introduction}

In recent years the comply-or-explain approach for designing and enforcing corporate governance norms has gained ground in regulatory parlance. Under the comply-or-explain approach governance norms are tailored to the specific characteristics of individual companies which is believed to lead to more efficient governance outcomes compared to the presumably "one size fits all" approach that is often argued to be inherent in the comply-or-else approach. A comply-orexplain approach could be particularly important for emerging economies where organization, ownership and control structure of companies are complex and where optimal governance mechanisms that maximize company value are in the process of evolution. Yet, the very same features of emerging economies that increase the attractiveness of the comply-or-explain approach also pose large challenges for implementation. In particular, the complexity of organization, ownership and control structure coupled with lower transparency of operation of companies can put large burden on the regulator to determine what structures are appropriate for good governance and then enforce them strictly. Similarly, the lower efficiency of the stock market and the relative lack of financial expertise on part of the average shareholder can make these complementary mechanisms which are crucial for the success of the comply-or-explain approach, less effective in emerging economies. What then are the relative advantages of the comply-or-explain approach vis-à-vis the more traditional comply-or-else approach and what are the specific institutional conditions which are required for its success in achieving effective governance of companies? This article is an attempt to answer these questions.

\subsection{The Two Approaches and Its Adoption around the World}

Under the comply-or-else approach the regulators prescribe a set of rules which all companies are required to comply with. These rules are generally introduced through legal statues. If a company does not comply with the rules then the company is liable to be penalized by the regulator. Penalties could be in the form of fines levied on the corporation or its directors as well as imprisonment of its officers. The comply-or-else approach is often characterized as a 'one-sizefits-all' approach since 'uniform standards' are prescribed for all companies and non-compliance directly leads to penalties, with the law not going any deeper into the reasons for non-compliance. 
In contrast, under the comply-or-explain approach the regulator specifies a set of codes and principles which act as guidelines or norms for all companies. Being recommendatory in nature, compliance is not mandatory. However, in case a company decides to deviate from any specific code or principle it must offer an explanation to the regulator. If the explanation is judged as sufficient, the company is allowed to make the deviation; if not, the company becomes liable to penalties imposed by the regulator. The comply-or-explain approach is perceived to give flexibility to a company to adopt the governance structure that is most appropriate for its operation which in turn is likely to lead to better governance outcomes.

In recent years, another approach called the apply-or-explain approach has gained ground. The apply-or-explain approach is a reformulated version of the comply-or-explain approach. Implicit in the comply-or-explain approach is the fact that a company that has offered an explanation, whether sufficient or insufficient, must have not-complied with some of the stated principles or codes. Thus, offering of explanation is synonymous with non-compliance. A more appropriate characterization can be achieved by renaming the approach as apply-or-explain. This way, applying the prescribed codes or explaining why they were not applied both become valid ways of compliance This minor change in terminology is believed to help promote the view among shareholders that 'greater' attention should be paid to the explanations.

Given these three alternative approaches to regulatory enforcement, what is the extent of their adoption around the world? Table 1 gives the details. It is apparent that most of the major countries around the world are following the comply-or-explain approach for corporate governance. These include the United Kingdom, Australia, Canada, Germany, Hong Kong, Singapore, all OECD ${ }^{2}$ member countries except for the US (OECD, 2004) and a host of other emerging economies. The two notable exceptions are the US and India which are following the comply-or-else approach. Significantly, the US is a very mature economy with a governance system that has evolved over a large number of years. In contrast, India is a fast growing emerging economy with evolving standards for corporate governance. South Africa is the only country that follows the apply-or-explain approach.

\footnotetext{
${ }^{2}$ Organization for Economic Co-operation and Development
} 
The large scale adoption of the comply-or-explain approach by many countries suggests that it has its own merits. But at the same time, the adoption of the comply-or-else approach by the US and India also raises a valid question of whether the comply-or-else approach could be better under certain institutional conditions. To address this issue it is instructive to understand the merits of the comply-or-explain vis-à-vis the comply-or-else approach and the pillars on which the former concept stands.

\subsection{The Structure of the Comply-or-Explain Approach}

Figure 1 presents the comply-or-explain approach and the comply-or-else approach in a schematic form. It is obvious that in the way that it is structured in theory, the comply-or-explain approach should be at least as good as the comply-or-else approach since the comply-or-else approach is but one node in the comply-or-explain approach. In the comply-or-explain approach, if the regulator choses the codes and principles to be the same as the rules specified under the comply-or-else approach and regards all explanations for deviation as insufficient, then the comply-or-explain approach will reduce to the comply-or-else approach. In addition, the comply-or-explain approach contains one node in which the regulator might allow deviations from the prescribed norms provided the company is able to justify those deviations. It is generally argued that the business conditions for companies vary based on their size and complexity which might make it in-optimal to have a uniform set of rules for all. Thus the comply-or-else approach should dominate the comply-or-else approach in totality. But then, why is the comply-or-explain approach not the only approach that all regulators ought to adopt?

The schematic diagram is now helpful. Looking at the diagram and starting from the end, the superiority of the comply-or-explain approach relies critically on judging the sufficiency of the explanations offered for deviations from the prescribed norms. Allowing a company to depart from the so called 'one-size-fits all' or 'uniform standards' and letting them adopt a structure that best suits their needs should be always better. But this is assuming that the company, or more specifically its managers, will adopt governance structures that deviate from the specified codes and principles only when doing so is in the best interest of the shareholders. However, if we acknowledge that the agency problem related to governance is an issue, which we must because otherwise the issue of governance becomes moot, then we must also acknowledge that there will 
be some companies whose managers have incentives to adopt structures that are in their own interest and not that of the shareholders and may therefore offer explanations to support the choice of those inappropriate structures.

The point that managers or insiders may take decisions which are not in the best interest of shareholders is sometimes misunderstood. This observation is interpreted as a commentary on the trustworthiness, ethics and integrity of managers and, in the extreme form, a supposition that managers might embezzle shareholder funds. However, this is simply the recognition of the fact that the actions taken by managers may benefit the shareholders and the managers in different ways and since managers usually make the choice, they might take those actions which are in their relative interest vis-à-vis that of the shareholders. The empirical literature on corporate governance is abound with evidence that managers sometimes do take actions that further their own interest vis-à-vis that of the shareholders, for example by undertaking negative net present value projects only for their personal empire building, or by managing earnings to increase their remuneration (Leuz et al., 2003; Haw et al., 2004). This problem of in-optimal decision is further exacerbated when large shareholders are also the managers of companies, as is characteristic of many emerging economies. In this case, the inside manager cum shareholder can take actions at the expense of the outside minority shareholders. Here too, the empirical literature on governance has produced evidence that expropriation of minority shareholders by dominant insider shareholders do take place (La Porta et al., 1999; La Porta et al., 2000).

The above discussion implies that while some managers may opt to deviate from the specified codes or principles which are in genuine interest of all shareholders, some managers and insiders may like to adopt governance structures that further their own interest at the expense of outside shareholders and then offer explanations to justify those structures. These explanations must then be detected as insufficient under the comply-or-explain approach. The logical question then is to ask who judges the sufficiency of the explanations and how does one decide if an explanation is sufficient or not? The comply-or-explain approach relies on three potentials "judges" to make this determination namely, (i) the shareholder, (ii) the financial market and (iii) the regulator. Let us consider them in turn. 


\subsection{The "Judges"}

\subsubsection{The shareholder}

In the comply-or-explain approach, the explanations offered by companies who deviate from the specified codes and principles are usually made public, perhaps put up on the website of the regulator or transmitted to an investor forum. The shareholders are then expected to judge if the explanations offered by the companies are sufficient to warrant the deviations. Are shareholders competent to make this determination? The relevant point to notice here is that the codes and principles that are specified by the regulators under the comply-or-explain approach are well thought out and are expected to work for most companies. The specified codes and principles in some sense are the "norms" that have been established by historical evolution of good governance structures, possibly supported by academic research. If these codes and principles are not complied with then the reason for deserving violations must be for extraordinary cases. Will the shareholders, who are not as informed as the managers, be sophisticated enough to make this determination?

Here the distinction between codes and principles become important. Under the comply-or-explain approach, a principle is usually a normative statement about what a good governance structure aims to achieve, while a code is a positive statement suggesting one particular way (and possibly the "usual" way) in which that principle can be implemented. For example, a good governance principle is that the Board of Directors must be able to exercise independence of judgement, while a code is that the Board could have at least majority of its directors as independent. Should a company desire to have only one-third of its Board to consist of independent directors and then offer explanations to support that structure, will the average investor be competent to make this determination? This determination can become even more challenging when the comply-orexplain offers only principles but does not offer any accompanying code as a guidance of how that principle could be implemented.

The UK Governance Code, for example, comprises of 18 main principles which form the spirit of governance, and 55 code provisions. The codes act as guidelines for achieving the main principles and are easier to assess compliance, but may still be deviated from if satisfactory explanations for the same are provided. For example, under "Division of Responsibilities", the principle states that 
"there should be a clear division of responsibilities at the head of the company between the running of the board and the executive responsibility for the running of the company's business. No one individual should have unfettered powers of decision." Then there is an accompanying code which sets out a more definitive framework for application of the principle with "the roles of chairman and chief executive should not be exercised by the same individual. The division of responsibilities between the chairman and chief executive should be clearly established, set out in writing and agreed by the board." In contrast in China, the Code of Corporate Governance only lists out 95 principles of corporate governance, "in whose spirit, listed companies are supposed to act", but there are no guided codes to ensure, for example, what an independent director on the board of directors might mean, and in what proportion should they be present on the Board. Board independence and CEO-Duality, among others, are highly debated issues in corporate governance and it is possibly too ambitious to assume that an average investor would be able to judge that a proposed deviation is in best interest of the shareholders.

A possible solution could be presence of large and active shareholders, like mutual funds, pension funds, and other institutional investors with specialized knowledge who might have both the expertise to discriminate between "good" and "bad" deviations as well the ability to force the management to abandon the "bad" structures which are not in the best interest of the shareholders by "voting with their feet." In many countries, however, outside ownership can be dispersed, and individual shareholders may neither have the incentive nor the power to force management to abandon in-optimal deviations even if they somehow detected those structures.

This brings to the second problem of relying on shareholder as the "judge" under the comply-orexplain approach namely, that of free riding. Since the average investor holds but only a tiny fraction of the total shares of the company, his or her individuals decision does not affect the outcome of whether an explanation is judged as sufficient or not by other investors. At the same time, by not taking the costly effort to make this determination, the investor can gain from the decision taken by other investors. Of course, since every investor can think like this, the effort to make the determination of whether a different structure is good or not, never gets taken and therefore in-optimal structures are never detected by the shareholders. It may be argued that shareholders, like the analyst, are smart enough to recognize this free rider problem and may, 
therefore, be inclined to take the effort to discriminate between "good" and "bad" structures. Even, if one were to assume this, it may not make economic sense for an individual shareholder to actually do this. Since, the average shareholder is very small, it will take significant effort on his/her part to coordinate with other small shareholders to force the managers to take back inoptimal structures, and the benefit of doing so, being distributed among a large number of small shareholders, may not provide sufficient economic incentive to the individual shareholder to undertake this effort. In summary, the absence of sufficient expertise, the free riding problem and the lack of economic incentive, can prevent the shareholder to act as the "judge" under the comply-or-explain approach.

\subsubsection{The Financial Market}

The financial market is the next "judge" under the comply-or-explain approach. Since the explanations offered by companies are publicly available, the shares of the companies whose explanations are found to be insufficient may be just offloaded in the financial market leading to a sharp drop in the share prices and consequently in the market value of the company. This in turn would act as a threat to managers from deviating from the prescribed codes and principles unless they are in the shareholders' interest. In this case, the "legal sanction" under the comply-or-else approach is replaced by "market sanction" under the comply-or-explain approach (Mirza and Mohanty, 2014).

The financial market as a "judge" to some extent gets rid of the incentive problem since the financial market combines the action of many investors thus avoiding the cost of coordination discussed earlier. However, notwithstanding this point, the financial market is but a collection of individual shareholders, so the problem of free riding and the lack of expertise suggested above still remain. The shareholder still has to make the determination of whether the explanations given by managers to make deviations from the prescribed codes are sufficient before she decides to offload her shares. In addition, making the financial market as the judge is a very costly way of enforcing rules. The greatest sufferers from the fall in share prices are the shareholders themselves whose interest the regulators aim to protect. Regulators around the world are generally reluctant to take punitive measures against companies which end up hurting the shareholders the most. For 
example, regulators generally refrain from delisting companies from exchanges recognizing that the ordinary shareholders would be the most affected party if such an action was actually taken.

It could be argued that the mere threat of fall in market value of the company might force companies and its managers to be truthful, so that in equilibrium the shares are never off-loaded in the market and the issue of hurting shareholders does not arise. While this argument does have some merit, it presupposes that financial market of the country is broad based with a minimum amount of public float, that managers are not dominant shareholders, the financial market is highly liquid with low transaction costs, and in general the financial market is efficient so that the fall in the share prices can be directly attributed to the action of the shareholders. These conditions are unlikely to be met in emerging economies. In contrast, under the comply-or-else approach, regulatory actions potentially involve fines as well as imprisonment of managers and other office bearers which can lead to better enforcement without hurting the shareholders directly.

\subsubsection{The Regulator}

The third and the most obvious choice for judging the sufficiency of the explanation is the regulator. The regulator is the most competent of the three possible "judges" under the comply-orexplain approach. It has the necessary expertise and incentive as well as the power to enforce its decisions. The regulator will still have to determine some benchmarks against which it has to judge the sufficiency of explanations offered by companies, but this task is simpler under the comply-or-explain approach than under the comply-or-else approach. In the comply-or-else approach the regulator has to a priori specify all possible codes or structures which could be valid ways of adhering to a principle, a task which is practically impossible since the regulator cannot foresee all situations in advance. In contrast, under the comply-or-explain approach the regulator has to make a determination of sufficiency only for those structures that are actually proposed as deviations by the companies or its managers.

Notwithstanding the incentive and the expertise, the main challenge the regulator faces in the comply-or-explain approach is the availability of adequate trained personnel at its disposal. Demand for expert staff is likely to be high as the regulator has to obtain, examine and assess the quality of explanations from companies who deviate from the prescribed codes and principles. 
This challenge could be especially high in emerging economies which are still evolving in terms of their governance standards and therefore do not have established benchmarks against which the regulator can judge sufficiency of alternatively proposed structures. Reference to governance benchmarks of developed economies could be only of limited assistance. There is increasing recognition both in the academic literature and in policy discourses that governance problems of emerging economies are different from those in developed economies and are shaped by their social, cultural and institutional factors. Accordingly governance structures that minimize agency costs in emerging economies are expected to be different from those that are suitable for developed economics. This problem of determining sufficiency of proposed structures could be further aggravated if there is considerable heterogeneity in organizational forms of companies within the country that makes it difficult to ascertain which governance structure is optimal for which type of companies. In such situation, there could be "too much work" to do for the regulator. In addition, while some proposed deviations could be genuine, i.e., that are in the interest of the shareholders, some deviations could be strategic i.e., in the interest of the managers or inside shareholders. The task of wedding out the strategic and in-optimal structures would add to the burden of the regulator. High penalty for wrongful and motivated explanations will be required to ensure that only genuine cases come up to the regulator for its judgement. Strict enforcement would substantially reduce the burden on the regulator and enable it to consider the genuine cases and allow those structures which add value for the company and its shareholders.

\subsection{Relative Importance of the Different Mechanisms}

The aforesaid discussion implies that the success of the comply-or-explain approach would have to rely heavily on the regulator playing the dominant role in enforcement, with the shareholders and the financial markets acting as complementary mechanisms. Of course, the relative importance of these three alternatives enforcement mechanisms will depend on their relative efficiency, namely the resources and the statutory powers at the disposal of the regulator, the expertise of the shareholders, and the efficiency of the stock markets. Table 2 illustrates the role envisaged of the regulator, shareholder and the financial market in the different countries that have adopted the comply-or-explain approach. 
It is clear that in many countries like France, Sweden, Belgium and Germany, the regulator has been assigned a major role in the enforcement of the codes and principles. The case of Belgium is particularly instructive. The Belgium Corporate Governance Code was drafted by the Financial Market Services Authority (FMSA) along with a congregation of stakeholders. The FMSA makes an in-depth analysis of compliance including a detailed description of the explanations given in case of non-compliance of any Code. In the Belgium Code, the Board of Directors plays an important role in fostering corporate governance and validating the explanations and is held responsible for it. The Belgian Commission of Corporate Governance has devised the following principles as a useful guide to improve the quality:

- Explanations cannot just refer to the fact that a company considers the recommendations of the code inappropriate.

- If a company deviates from a provision of the Code, the reasons why must be specified in the Corporate Governance statement to create more transparency.

- Companies should clearly mention which provisions of the code they are deviating from and then give the explanation.

- A description of these deviations must be submitted to the Board of Directors to verify the quality of each explanation and check whether there are any additional reasons why the company deviates from the Code.

- The Board of Directors must approve the reasons given and endorse their content.

- Explanations must be submitted to the General Assembly when the Corporate Governance Statement is presented.

The Swedish Code requires that a company should not only provide explanations for noncompliance but must also describe, for each case, the solution that it has adopted and provide explanations of the alternative. In France, the Association Française des Entreprises Privées (Afep) and Mouvement des Entreprises de France (Medef) have a High Committee for monitoring implementation of the Code, and have powers to initiate proceedings to seize Board of a noncompliant company whose explanations are deemed invalid or insufficient 
Other countries, like UK, South Korea, China, Brazil and South Africa have assigned the enforcement role primarily to the shareholder and the market. Notable among these is the United Kingdom from where the comply-or-explain code has originated, which has assigned to the shareholder the dominant role in adjudicating whether the explanations offered by companies are sufficient. In the comply-or-explain approach, the nature and relevance of explanations is paramount as the 'quality of the explanation' determines the imposition of penalty. In the UK's Code the shareholders are expected to carry out this job of monitoring and alert the market regulators if information is not available or the quality of explanation is not good enough.

Do shareholders carry out this role effectively and do companies actually provide high quality information for the shareholders to judge if explanations are sufficient? A study of the compliance behaviour of 254 listed companies belonging to the FTSE350 companies over an extended period of six years from 1998 to 2004 shows that over half (51\%) of the companies that did not comply with eight code provisions, did not provide any specific explanations while $17 \%$ provided no explanations at all (Arcot, Bruno 2006). It was also observed that when pointed out, very few companies moved from general to specific explanations till they directly jumped towards full compliance. In other words, the companies took little initiative to fine-tune their governance structures as there was practically no movement towards a better explanation. The absence of good quality explanation seems to suggest that shareholders' (who ultimately were the ones responsible for enforcement) do not pay attention to the details of an explanation. Shareholders were generally more concerned as to whether there has been compliance or not and shareholder pressure was targeted directly to compliance than explanations and it usually succeeded after a 'bad performance' by the company. A flexible Code like that of the UK is of value if the companies take the opportunity of fine tuning their governance systems based on their needs and are able to justify those deviations. Flexibility when accompanied by 'poor' explanations means that companies can follow 'non-compliance' and can get away with it at a relatively small cost. Thus the relative flexibility must be commensurate with the number of good explanations and not just mere compliance of the Code. 


\subsection{Pre-conditions for Adoption of the Comply-or-Explain Approach}

The aforesaid discussion implies that the success of the comply-or-explain approach will depend on a large extent on the transparency of operation of companies and on the general belief that good governance is a desirable goal. This would make managers adopt alternative structures only when these are in the best interest of the shareholders and provide adequate explanations for doing so which in turn should reduce the burden on the regulators. The success will also depend on the emergence of governance benchmarks and acceptable governance norms that would make it easier for the regulator to implement the comply-or-explain approach. Converging to such benchmarks may be slower in case a country where the ownership and control structures of companies are complex thereby raising the possibility of multiplicity of standards. Finally the success of the comply-or-explain approach will depend on strong regulatory enforcement as well as activism of the shareholder, especially institutional shareholders, and the operation of an efficient stock market that act as complementary enforcement mechanisms.

In the long run as alternative governance structures that are consistent with the specified principles emerge, the currently specified codes can be expanded to incorporate these structures. The specified codes would then take into account the business conditions of most companies. At the same time, as the economy matures and enforcement becomes stronger, less strategic violations will occur. Accordingly, governance will largely be a matter of enforcement and the comply-orexplain approach will reduce to the comply-or-else approach. In this connection it should be noted that the comply-or-else approach as practised in India and the US cannot be strictly described as a "one size fits" all approach. First, many of the rules, especially those related to board, audit committee, remuneration committee and nomination committee, composition are specified as percentages of the size of the board and the respective committees. This obviously gives companies flexibility in terms of absolute numbers based on their size. There are also deeper flexibilities that are allowed. For example, the New York Stock Exchange Listing Rules in the US only specify some necessary conditions for director independence and allows companies to make affirmative determination if a director should be considered independent or not. Similarly, the NYSE Rules only sets an advisory that independent directors serving on the audit committee ought not to have more than three directorships but allows flexibility to companies who wish hire directors with more than three directorships by citing valid reasons for such appointments. 
Likewise the Clause 49 Regulations in India gives flexibility to companies to have its Board consist of a majority or one third of its members as independent directors based on whether it wants to have an executive or non-executive chairman. Thus, in the long run the comply-orexplain approach could gravitate to comply-or-else approach with the exceptions included in the rules itself. This would enable the regulator to focus on the single point agenda of enforcement without having to spend substantially time and effort to validate alternative structures. In this sense the comply-or-explain approach can be looked at as a transitory process to discovering the optimal set of governance structures that can then be codified into a comply-or-else approach that would be efficient in the dynamic sense.

Given the above discussions what should be our prediction of the probability of adoption of the comply-or-explain approach? Clearly this will depend on the one hand on the transparency of operation of the companies and their willingness to truthfully adopted governance structures that are in the best interest of the shareholders and on the other hand on the resources that are available to the regulator to recognize efficient governance structures that could be genuine deviations from the specified codes and principles as well as its power of its enforcement. If we take these demand and supply forces simultaneously into account and call the resulting situation as the "governance challenge", then our discussion implies that we should see inverted U-shaped relation between the "challenge of governance" and the relative adoption of the comply-or-explain approach (Figure 2).

In the early stages of evolution when governance standards are being established both from the viewpoint of the companies as well from the side of the regulator, the governance challenge is likely to be high and we would expect the comply-or-explain approach to be less suitable. As time evolves and governance standards get established, the incentive of the companies to adopt good governance practices as well as the effectiveness of the regulator to judge alternative structures increases. In this case the benefit from allowing flexibility outweighs its cost, lowering the governance challenge and making the comply-or-explain approach a more attractive proposition. Finally when most governance standards have emerged, and the regulator becomes fully effective, the governance challenge further reduces to effective enforcement making the comply-or-else, with flexibility, as the ultimate choice. 
How does the actual adoption of the comply-or-explain approach fit our prediction? As outlined earlier, India and the US are the two countries that have adopted the comply-or-else approach. India is an emerging economy with an evolving governance structure. While its governance structure may be relatively more matured than other emerging economies, the governance challenge in India is high given the complex ownership structure of Indian companies, the large presence of controlling shareholders in managerial positions and the dominance of business groups many of which are organized of form of complex pyramids. Simultaneously, the quality of financial disclosures made by Indian companies, though improving over the years, needs to be further strengthened. The "corporate governance report required to be incorporated in every annual corporate report often contains no information that could explain the quality of governance and has standard statements that are repeated each year (Mirza and Mohanty, 2014)." Activism by institutional investors which could be a potential driving force for ensuring compliance is also not at the level present in the UK and the financial market is still evolving. Under such circumstances, even if the regulator is as competent as others, it makes sense for India to adopt the comply-or-else approach until governance practices improve and clear governance standards emerge.

In contrast, notwithstanding some of the corporate failures, the US is probably the country with the most evolved corporate sector where ownership and organization structure of companies have stabilised over time and governance norms already accommodate these structures to ensure effective governance. In such a scenario it makes sense for the regulator to choose the comply-orelse approach and focus primarily on enforcement with some flexibility built in the specified governance rules. The European countries like UK, France, Germany, Belgium and Sweden can be viewed as in advance stages of the comply-or-explain approach with detailed specification of principles and codes with the regulator playing an active role in enforcement. The notable exceptions seem to be South Africa and Brazil which have adopted the comply-or-explain approach though their governance structures are in the early stages of evolution. Perhaps the organization structure of the companies in these countries is simpler so that the governance challenge is relatively low or that these countries have put more emphasis on the flexibility that companies need to be given to improve their performance though strong enforcement of governance standards could probably achieve the same objective. Whatever be the reasons, the 
choice between the comply-or-else approach and the comply-or-explain approach to regulatory compliance will be a highly debated topic in the coming few years.

\section{References}

1. Arcot, S.R. and V.G.Bruno, 2006. In Letter but not in Spirit: An Analysis of Corporate Governance in the UK, mimeo, Financial Markets Group, London School of Economics.

2. Haw, I., B. Hu, L. Hwang and W. Wu., 2004. Ultimate Ownership, Income Management and Legal and Extra-Legal Institutions. Journal of Accounting Research, 42(2): 423-62.

3. La Porta Rafael, Florencio Lopez-de-Silanes, Andrei Shleifer, 1999, Corporate Ownership Around the World, Journal of Finance, 54(2), pp. 471-517.

4. La Porta , R. Florencio Lopez-de-Silanes, Andrei Shleifer, 2000. Investor Protection and Corporate Governance, Journal of Financial Economics, 58(3), pp. 3-29.

5. Leuz, C., Nanda, D., and Wysocki, P. 2003. Earnings management and investor protection: An international comparison. Journal of Financial Economics, 69: 505-527.

6. Mirza, Nawshir and Nirmal Mohanty, 2014. Comply or Explain - A Alternative Approach to Corporate Governance, Quarterly Briefing, No. 4, National Stock Exchange of India.

\section{The Codes}

7. Appendix 14 Corporate Governance Code Hong Kong Exchanges and Clearing Limited (HKEx), 2005, https://www.hkex.com.hk/eng/rulesreg/listrules/mbrules/documents/appendix_14.pdf

8. Australian Securities Exchange (ASX) Corporate Governance Principles, 2010, http://www.asx.com.au/documents/asxcompliance/cg_principles_recommendations_with_2010_amendments.pdf

9. Clause 49 of Listing Agreeement, 2013 Amendment, 2013, http://www.sebi.gov.in/cms/sebi data/attachdocs/1410777212906.pdf

10. Clause 49 of Listing Agreement, 2000, http://nseindia.com/getting_listed/content/clause_49.pdf

11. Code of Best Practice for Corporate Governance, South Korea, 2003, http://www.eiod.org/uploads/Publications/Pdf/korea_2003_en.pdf 
12. Code of Corporate Governance for Listed Companies, China, 2002, http://www.ecgi.org/codes/documents/code en.pdf

13. Corporate Governance Code of Listed Corporations (From Vienot I Report), 2010, http://www.medef.com/fileadmin/www.medef.fr/documents/AFEP-MEDEF/Guide_AFEPMEDEF An 18-11.pdf

14. Corporate Governance Code, Belgium, 2009, http://www.ecgi.org/codes/documents/cg_code_belgium_12mar2009_en.pdf

15. Cromme Code of Corporate Governance, 2014, http://www.dcgk.de//files/dcgk/usercontent/en/download/code/E-CorpGov_2014.pdf

16. Indonesian Code of Good Corporate Governance, 2006, http://www.acgaasia.org/public/files/Indonesia\%20Code\%20of\%20GCG\%202006.pdf

17. King III Corporate Governance Code, 2012 Amendment, 2012, http://c.ymcdn.com/sites/www.iodsa.co.za/resource/collection/94445006-4F18-4335-B7FB7F5A8B23FB3F/King_Code_of_Governance_for_SA_2009_Updated_June_2012.pdf

18. Malaysian Code on Corporate Governance, 2012, http://www.mia.org.my/new/downloads/circularsandresources/circulars/2012/21/MCCG_2012.pdf

19. Novo Mercado Corporate Governance BOVESPA Listing Rules, 2009, http://www.ecgi.org/codes/documents/ibcg_sep2009_en.pdf

20. OECD Principles of Corporate Governance, 2004, http://www.ecgi.org/codes/documents/principles en final.pdf

21. Sarbanes-Oxley Act, 2003, (NYSE Listing Rules, 2003)

http://www.ecgi.org/codes/documents/finalcorpgovrules.pdf

22. Singapore Code of Corporate Governance, 2012, http://www.acga-asia.org/public/files/(02-0512)cgcrevisedcodeofcorporategovernance\%20(MAS).pdf

23. Swedish Code of Corporate Governance, 2010, http://www.corporategovernanceboard.se/media/45322/svenskkodbolagsstyrn_2010_eng_korrigerad20 110321.pdf

24. UK Governance Code, 2014, https://www.frc.org.uk/Our-Work/Publications/CorporateGovernance/UK-Corporate-Governance-Code-2014.pdf

25. Unified Good Governance Code, Spain, 2006, http://www.ecgi.org/codes/documents/unified code may2006 en.pdf 
Table 1: Adoption of Alternative Approaches to Corporate Governance

\begin{tabular}{|l|l|l|l|}
\hline Country & Year & Name of Regulation/Code & $\begin{array}{c}\text { Comply-or-else } \\
\text { or } \\
\text { Comply-or-explain }\end{array}$ \\
\hline USA & 2002 & Sarbanes-Oxley Act & Comply-or-else \\
\hline India & 2000 & Clause 49 of Listing Agreement & Comply-or-else \\
\hline U.K. & 1992 & UK Governance Code (from Cadbury Report) & Comply-or-explain \\
\hline France & 1995 & Corporate Governance of Listed Corporations (From Vienot I Report) & Comply-or-explain \\
\hline South Korea & 1999 & Code of Best Practice for Corporate Governance & Comply-or-explain \\
\hline Malaysia & 2000 & Malaysian Code on Corporate Governance & Comply-or-explain \\
\hline Brazil & 2001 & Novo Mercado Corporate Governance BOVESPA Listing Rules & Comply-or-explain \\
\hline Singapore & 2001 & Singapore Code of Corporate Governance & Comply-or-explain \\
\hline Germany & 2002 & Cromme Code of Corporate Governance & Comply-or-explain \\
\hline China & 2002 & Code of Corporate Governance for Listed Companies & Comply-or-explain \\
\hline OECD & 2004 & OECD Principles of Corporate Governance & Comply-or-explain \\
\hline Hong Kong & 2005 & Appendix 14 Corporate Governance Code HKEx & Comply-or-explain \\
\hline Spain & 2006 & Unified Good Governance Code & Comply-or-explain \\
\hline Australia & 2007 & Australian Securities Exchange Corporate Governance Principles & Comply-or-explain \\
\hline Sweden & 2008 & Swedish Code of Corporate Governance & Comply-or-explain \\
\hline Belgium & 2008 & Corporate Governance Code & Comply-or-explain \\
\hline Indonesia & 2014 & Indonesian Good Corporate Governance (GCG) Roadmap & Comply-or-explain \\
\hline South Africa & 2010 & King III Corporate Governance Code & Apply-or-explain \\
\hline
\end{tabular}




\section{Figure 1: Comply-or-Explain versus Comply-or-Else}

\section{Comply-or-Explain}

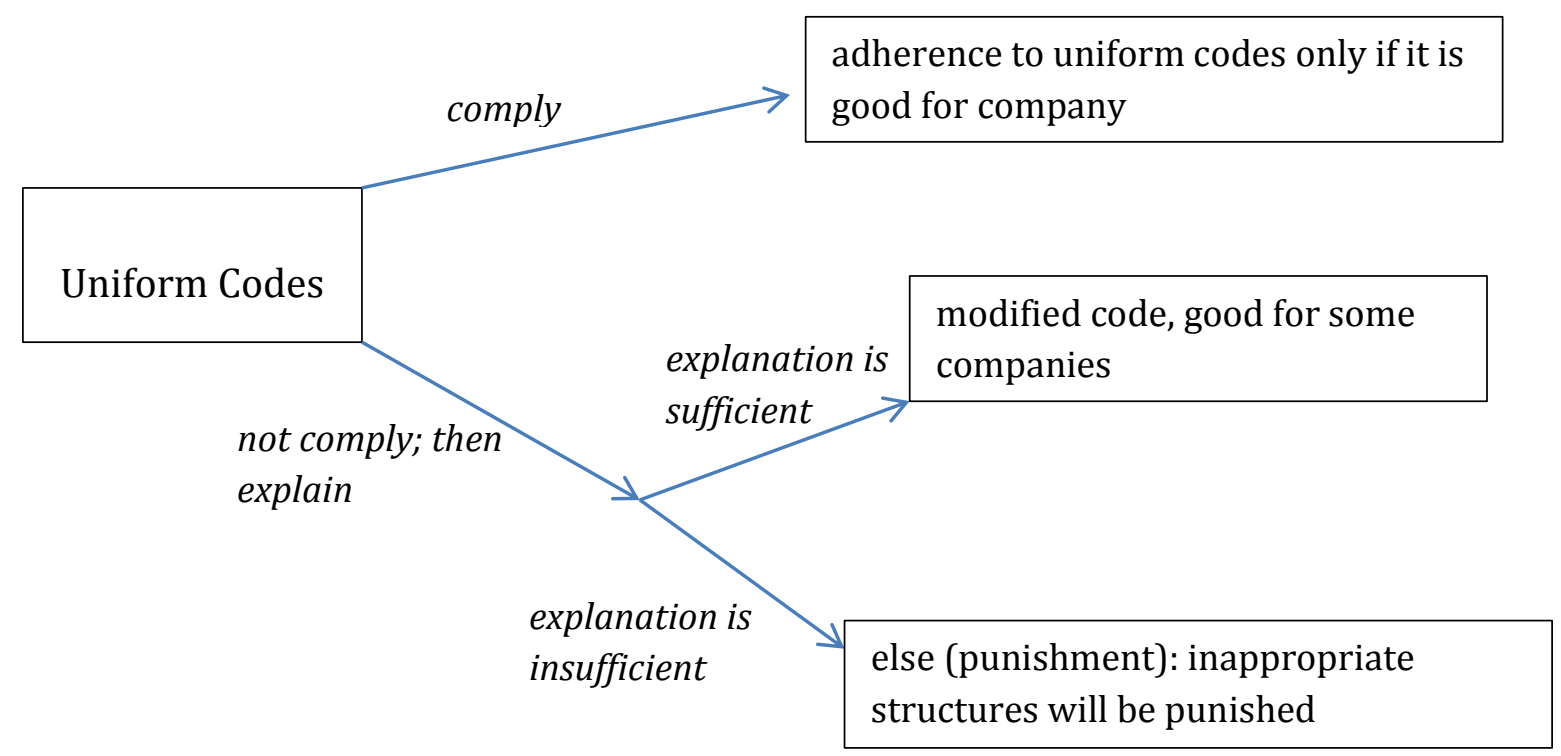

Comply-or-Else

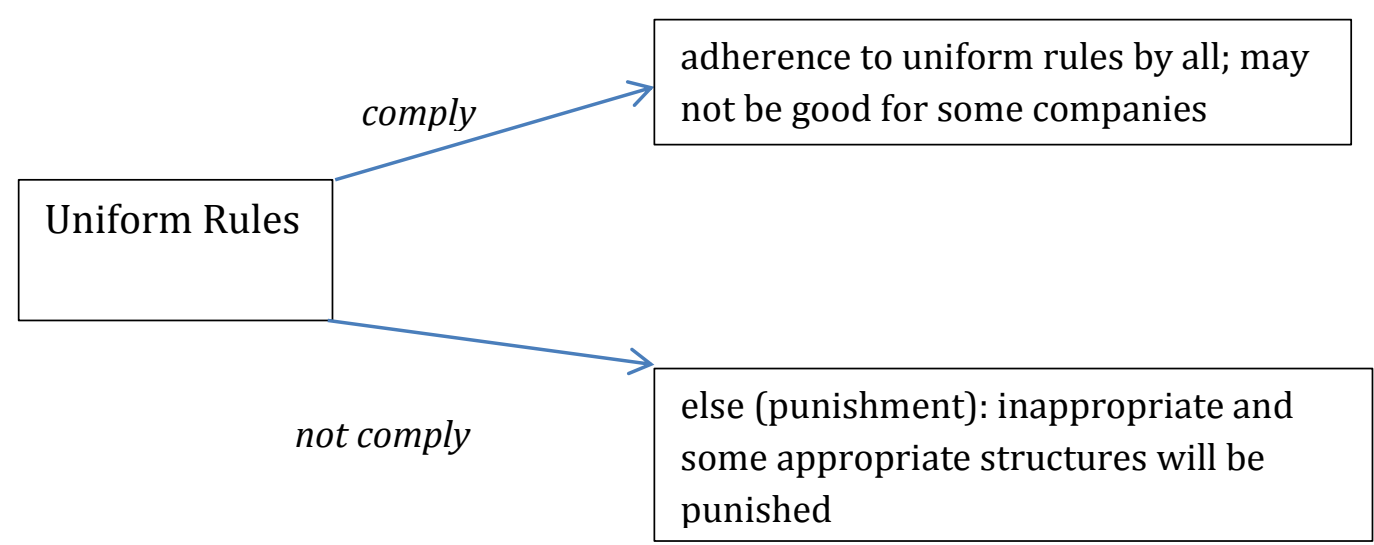


Table 2: Mechanism of Enforcement of Governance Norms Approach around the World

\begin{tabular}{|c|c|c|c|c|c|}
\hline Country & Year & Name of Regulation/Code & $\begin{array}{l}\text { Comply-or-else } \\
\text { or } \\
\text { Comply-or- } \\
\text { explain }\end{array}$ & Regulation/Enforcement of Code & Primary Enforcer \\
\hline USA & 2002 & Sarbanes-Oxley Act & Comply-or-else & $\begin{array}{l}\text { Companies convicted by Securities and Exchange } \\
\text { Commission (SEC) are required to pay fines or face } \\
\text { imprisonment }\end{array}$ & Regulator \\
\hline India & 2000 & Clause 49 of Listing Agreement & Comply-or-else & $\begin{array}{l}\text { Securities and Exchange Board of India (SEBI) directs } \\
\text { impositions of fines on noncompliant firms and } \\
\text { suspension of trade in their shares }\end{array}$ & Regulator \\
\hline U.K. & 1992 & $\begin{array}{l}\text { UK Governance Code (from Cadbury } \\
\text { Report) }\end{array}$ & $\begin{array}{l}\text { Comply-or- } \\
\text { explain }\end{array}$ & $\begin{array}{l}\text { Enforcement of code left to shareholders, it is upto } \\
\text { them to judge quality of explanations and inform the } \\
\text { Financial Reporting Council (FRC) of any discrepancies }\end{array}$ & $\begin{array}{l}\text { Shareholder } \\
\text { Regulator }\end{array}$ \\
\hline France & 1995 & $\begin{array}{l}\text { Corporate Governance of Listed } \\
\text { Corporations (From Vienot I Report) }\end{array}$ & $\begin{array}{l}\text { Comply-or- } \\
\text { explain }\end{array}$ & $\begin{array}{l}\text { Association Française des Entreprises Privées (Afep) } \\
\text { and Mouvement des Entreprises de } \\
\text { France (Medef) have a High Committee for monitoring } \\
\text { implementation of code, and may initiate proceedings } \\
\text { to seize Board of a non-compliant company whose } \\
\text { explanations are deemed invalid or insufficient }\end{array}$ & Regulator \\
\hline $\begin{array}{l}\text { South } \\
\text { Korea }\end{array}$ & 1999 & $\begin{array}{l}\text { Code of Best Practice for Corporate } \\
\text { Governance }\end{array}$ & $\begin{array}{l}\text { Comply-or- } \\
\text { explain }\end{array}$ & $\begin{array}{l}\text { Information is disclosed to the market. Suggestions } \\
\text { are made to form a governing agency where } \\
\text { shareholders can mediate disputes rather than } \\
\text { lengthy legal proceedings, however none exist yet. }\end{array}$ & $\begin{array}{l}\text { Shareholder } \\
\text { Market }\end{array}$ \\
\hline Brazil & 2001 & $\begin{array}{l}\text { Novo Mercado Corporate } \\
\text { Governance BOVESPA Listing Rules }\end{array}$ & $\begin{array}{l}\text { Comply-or- } \\
\text { explain }\end{array}$ & Information is disclosed to the shareholders to judge & Shareholder \\
\hline Germany & 2002 & $\begin{array}{l}\text { Cromme Code of Corporate } \\
\text { Governance }\end{array}$ & $\begin{array}{l}\text { Comply-or- } \\
\text { explain }\end{array}$ & $\begin{array}{l}\text { Explanations (of deviations from Recommendations", } \\
\text { but not "Suggestions") of the Code is required by } \\
\text { Section } 161 \text { of Aktiengesetz. Information is disclosed } \\
\text { to market through Annual CG Reports }\end{array}$ & $\begin{array}{l}\text { Regulator } \\
\text { Market }\end{array}$ \\
\hline
\end{tabular}




\begin{tabular}{|c|c|c|c|c|c|}
\hline China & 2002 & $\begin{array}{l}\text { Code of Corporate Governance for } \\
\text { Listed Companies }\end{array}$ & $\begin{array}{l}\text { Comply-or- } \\
\text { explain }\end{array}$ & $\begin{array}{l}\text { The China Securities Regulatory Commission (CSRC) is } \\
\text { responsible for the interpretation of the principles, it } \\
\text { may evaluate the corporate governance status of } \\
\text { companies itself, r outsource it to independent } \\
\text { agents, and make public the result of these } \\
\text { evaluations, if deemed appropriate }\end{array}$ & $\begin{array}{l}\text { Regulator } \\
\text { Market }\end{array}$ \\
\hline OECD & 2004 & $\begin{array}{l}\text { OECD Principles of Corporate } \\
\text { Governance }\end{array}$ & $\begin{array}{l}\text { Comply-or- } \\
\text { explain }\end{array}$ & $\begin{array}{l}\text { Principles are aimed at helping national legislators } \\
\text { form Codes, they are not binding. Countries are } \\
\text { advised to create their own regulatory and monitoring } \\
\text { mechanisms }\end{array}$ & $\begin{array}{l}\text { As required by } \\
\text { respective member } \\
\text { states }\end{array}$ \\
\hline Spain & 2006 & Unified Good Governance Code & $\begin{array}{l}\text { Comply-or- } \\
\text { explain }\end{array}$ & $\begin{array}{l}\text { The Comisión Nacional del Mercado de Valores } \\
\text { (CNMV) monitors implementation of the Code and } \\
\text { analyses validity, however does not act on deviations } \\
\text { as evaluations are left to market }\end{array}$ & Market \\
\hline Sweden & 2008 & $\begin{array}{l}\text { Swedish Code of Corporate } \\
\text { Governance }\end{array}$ & $\begin{array}{l}\text { Comply-or- } \\
\text { explain }\end{array}$ & $\begin{array}{l}\text { Not only must non-compliances be reported, but also } \\
\text { describe solution and what they see as good } \\
\text { governance, the Swedish Securities Council (SSC) } \\
\text { might issue reports on how Code should be } \\
\text { interpreted to help shareholders }\end{array}$ & Regulator \\
\hline Belgium & 2008 & Corporate Governance Code & $\begin{array}{l}\text { Comply-or- } \\
\text { explain }\end{array}$ & $\begin{array}{l}\text { The Belgian Commission for Corporate Governance } \\
\text { monitors implementation of the Code, provides a } \\
\text { framework for evaluation and ensures the Code's } \\
\text { provisions remain relevant to listed companies, are } \\
\text { updated regularly in line with practice, legislation and } \\
\text { international standards. Explanations for non- } \\
\text { compliance of Code must be set before the Board of } \\
\text { Directors, and the Financial Services and Markets } \\
\text { Authority (FSMA). }\end{array}$ & Regulator \\
\hline $\begin{array}{l}\text { South } \\
\text { Africa }\end{array}$ & 2010 & King III Corporate Governance Code & Apply or Explain & $\begin{array}{l}\text { Companies Act } 71 \text { enforces some CG statutes. } \\
\text { Interpretation of deviations from Code are left to } \\
\text { shareholders, who are the "ultimate compliance } \\
\text { officers" }\end{array}$ & Shareholder \\
\hline
\end{tabular}


Figure 2: Likely Adoption of the Comply-or-Explain Approach

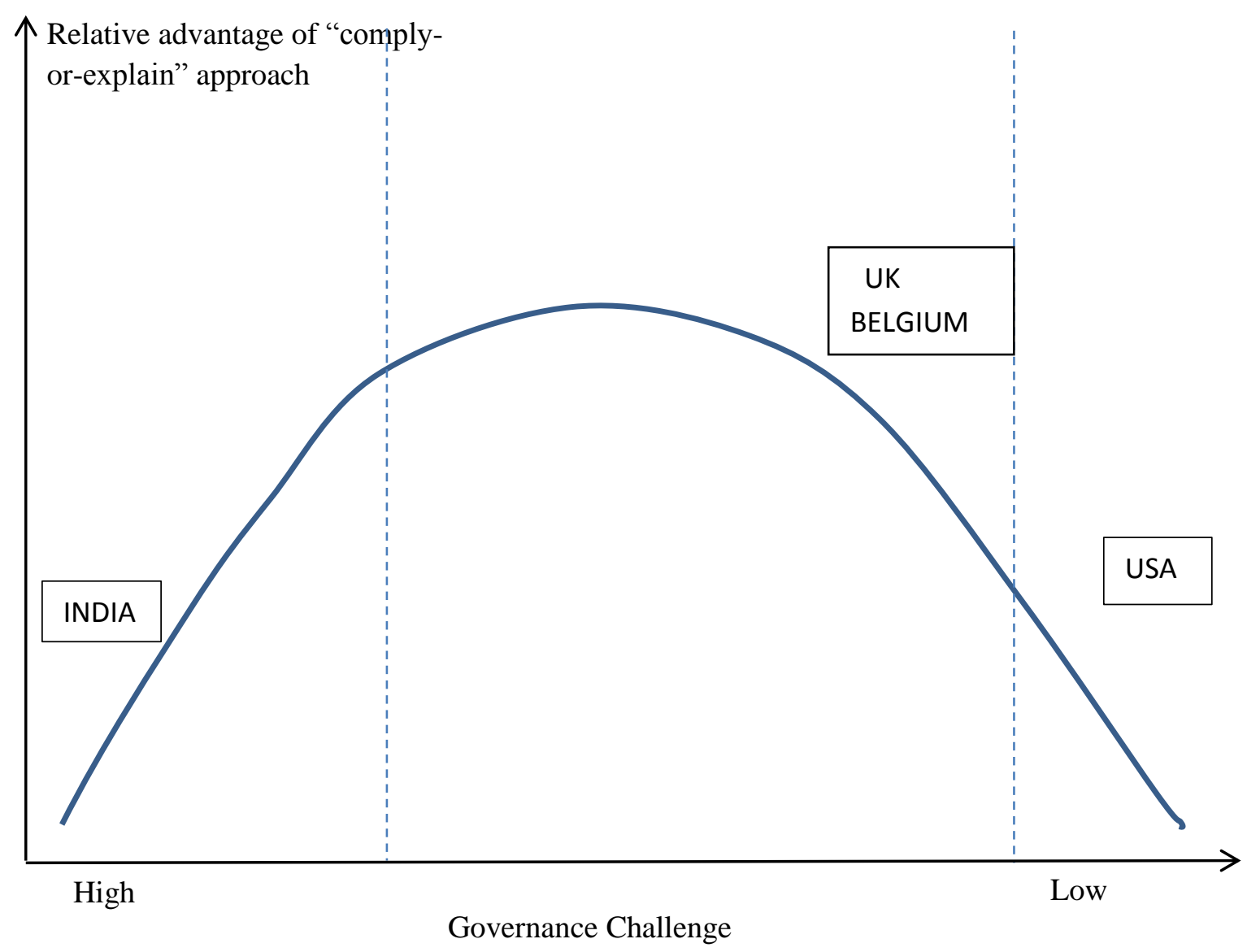

